\title{
Is protracted bacterial bronchitis a new nosological group or an old problem of differential diagnosis of chronic cough in children?
}

\author{
S. I. Ilchenko*A,B,C,F, A. O. Fialkovska ${ }^{\mathrm{C}, D, E}$, L. O. Zhukova ${ }^{\mathrm{B}, \mathrm{C}}$ \\ SI «Dnipropetrovsk Medical Academy of the Ministry of Health of Ukraine», Dnipro
}

A - research concept and design; B - collection and/or assembly of data; C - data analysis and interpretation; D - writing the article; $\mathrm{E}$ - critical revision of the article; $\mathrm{F}$ - final approval of the article

Key words: cough, bronchitis, chronic bronchitis, child.

Zaporozhye medical journal 2019; 21 (4), 466-470

DOl:

10.14739/2310-1210.

2019.4.173341

*E-mail:

ilchensv@gmail.com

The purpose is to study the clinical-anamnestic and microbiological features of the protracted bacterial bronchitis (PBB), recurrent bronchitis (RB), chronic bronchitis (CB) in children and to determine the risk factors for the development of chronic bronchitis.

Materials and methods. A total of 89 children were examined, among them 21 children with PBB, 27 children with RB and 41 children with CB. The study included the collection of anamnesis, objective examination, chest X-ray, bronchoscopy and microbiological examination of the bronchial mucosa and upper respiratory tract composition.

Results. An analysis of PBB clinical features showed that their total duration was $4.1 \pm 0.3$ weeks. In children with $\mathrm{RB}$, the duration of exacerbations did not differ significantly and was $3.8 \pm 0.4$ weeks. In patients with $\mathrm{CB}$, the annual number of bronchitis and the total duration of cough were two times higher than in patients with RB. Bacteriological analysis showed that Streptococcus pneumonia was the most frequent causative agent of the disease in children with PBB and RB. In children with exacerbation of $\mathrm{CB}$, Haemophilus influenzae was more commonly identified. At the same time, such a representative of the normal bronchial microbiome as Aerococcus viridans, was identified in $81.0 \%$ of PBB patients, in $33.3 \%$ of RB patients, and in $8.7 \%$ of CB patients. Conclusions. The study showed that risk factors for $\mathrm{CB}$ development in children with PBB and RB are the lower respiratory tract $H$. influenzae colonization and decreased activity or absence of the normal airway microbiota (Aerococcus viridans).

Ключові слова: кашель, затяжний бактеріальний бронхіт, рецияивний бронхіт, хронічний бронхіт, Аіти.

Запорізький медичний T. 21, № 4(115). C. 466-470 журнал. - 2019. -

\section{Затяжні бактеріальні бронхіти - нова нозологічна група або старі проблеми диференційної діагностики хронічного кашлю в дітей?}

\section{С. І. Ільченко, А. О. Фіалковська, А. О. Жукова}

Мета роботи - вивчити клініко-анамнестичні та мікробіологічні особливості затяжних бактеріальних бронхітів (ЗББ), рецидивного бронхіту (РБ), хронічного бронхіту (ХБ) у дітей і встановити фрактори ризику розвитку ХБ.

Матеріали та методи. Обстежили 89 дітей: 21 хворого на ЗББ, 27 дітей із РБ і 41 пацієнта з ХБ. Дослідження включало детальний збір анамнезу, об'єктивне обстеження дітей, рентгенографію органів грудної клітки, бронхоскопію та мікробіологічне дослідження складу слизової оболонки бронхів і верхніх дихальних шляхів.

Результати. Аналіз особливостей клінічного перебігу ЗББ показав, що загальна тривалість становила 4,1 $\pm 0,3$ тижня. У дітей із РБ тривалість загострень вірогідно не відрізнялася та становила 3,8 \pm 0,4 тижня. У хворих на ХБ кількість бронхітів на рік і загальна тривалість кашлю були вдвічі більшими, ніж у хворих на РБ. Бактеріологічний аналіз показав, що найчастішим збудником захворювання в дітей із ЗББ і РБ був Streptococcus pneumonia. У дітей із клінікою загострення ХБ частіше визначали Haemophilus influenzae. Такий представник нормальної мікрофлори бронхів, як Aerococcus viridans ідентифікували у 81,0 \% пацієнтів із ЗББ, у 33,3 \% дітей із РБ, у 8,7 \% хворих на ХБ.

Висновки. Дослідження показало, що факторами ризику розвитку ХБ у дітей із ЗББ і РБ є колонізація нижніх дихальних шляхів H. influenzae та зниження активності або відсутність нормальної мікрофрлори бронхів (Aerococcus viridans).

\section{Затяжные бактериальные бронхиты - новая нозологическая группа ияи старые проблемы дифференциальной диагностики хронического кашля у детей?}

кашель, бронхит,

хронический

бронхит, Аети.

Запорожский медицинский журнак. - 2019. T. 21, № 4(115). C. $466-470$

\section{С. И. Ильченко, А. А. Фиалковская, А. А. Жукова}

Цель работы - изучить клинико-анамнестические и микробиологические особенности затяжных бактериальных бронхитов (ЗББ), рецидивирующего бронхита (РБ), хронического бронхита (ХБ) у детей и определить фракторы риска развития ХБ.

Материалы и методы. Обследовали 89 детей: 21 пациента с ЗББ, 27 детей с РБ, 41 больного ХБ. Исследование включало детальный сбор анамнеза, объективное обследование детей, рентгенографию органов грудной клетки, бронхоскопию и микробиологическое исследование состава слизистой оболочки бронхов и верхних дыхательных путей.

Результаты. Анализ особенностей клинического течения ЗББ показал, что общая их продолжительность составила 4,1 \pm 0,3 недели. У детей с РБ продолжительность обострений достоверно не отличалась и составляла 3,8 $\pm 0,4$ недели. У больных ХБ количество бронхитов в году и общая продолжительность кашля были вдвое больше, чем у больных РБ. Бактериологический анализ мокроты показал, что наиболее частым возбудителем заболевания у детей с ЗББ и РБ был Streptococcus pneumonia. У детей с клиникой обострения ХБ чаще определяли Haemophilus influenzae. Такой предста- 
витель нормальной микрофрлоры бронхов, как Aerococcus viridans идентифицирован у 81,0 \% пациентов с 3ББ, у 33,3 \% больных РБ, у 8,7 \% детей с ХБ.

Выводы. Исследование показало, что фракторами риска развития ХБ у детей с ЗББ и РБ являются колонизация их нижних дыхательных путей $H$. influenzae и снижение активности или отсутствие нормальной микрофлоры бронхов (Aerococcus viridans).

\section{Introduction}

Cough is one of the most common symptoms of bronchitis in childhood. In most foreign recommendations on the classification of cough in children, for example, the British Thoracic Society, it is recommended to use the concepts "acute cough" is cough lasting 3 weeks, "chronic cough" is cough lasting 8 weeks. Prolonged acute cough is a "grey" area between acute and chronic cough, sometimes called "subacute cough" [1]. In domestic pulmonary practice in both children and adults, chronic cough is defined as a daily cough lasting more than 8 weeks [2]. While in the modern guidelines of the United States, Australia and New Zealand, chronic cough in children is defined as one that lasts more than 4 weeks [3].

For comparison, the duration of cough and the course of various forms of bronchitis according to International Classification of Diseases, 10th Revision (ICD-10), cough in children more than 8 weeks can be a symptom of only chronic bronchitis (J41), and long-lasting acute cough (4-8 weeks) - subacute bronchitis (J20). In the domestic pediatric pulmonary medicine, there is a problem of inconsistency between the national clinical classification of bronchitis in children and ICD-10. Thus, in the new clinical classification of bronchitis in children, which was adopted at the XIII Congress of Pediatricians of Ukraine (2016), there are acute, recurrent (there is no such form in ICD$10)$ and chronic bronchitis. According to the definition of this classification, "recurrent bronchitis (RB) is a bronchial disease with the recurrence of acute bronchitis episodes (2-3 times a year) for 1-2 years on the background of acute respiratory viral infections without signs of bronchial obstruction, characterized by a prolonged exacerbation (3-4 weeks and longer)". Chronic bronchitis (CB) is characterized by "the presence of productive cough for several months within two years, persistent moist rale, 2-3 exacerbations a year within two years". Thus, chronic cough, according to its course duration, can be both in case of RB and CB.

Today, the relatively new clinical nosology in children protracted bacterial bronchitis (PBB) - is being actively studied and discussed in the world. The PBB was first described in the study conducted in Australia in 2006 and is now included in the international cough guidelines [4]. PBB is characterized by an isolated chronic (lasting $>4$ weeks) wet or productive cough without signs of another cause, and usually responds to 2 weeks of an appropriate oral antibiotic [5]. Foreign studies show that PBB may be the most common cause for chronic wet cough in preschool children (0-6 years old) [6].

The prevalence of PBB among children with chronic wet cough in Ukraine is unknown, but many foreign studies report that its prevalence ranges from 10 to $40 \%$ in the population $[7,8]$. In the study by Gedik et al., which included 563 children with chronic cough, the most common final diagnosis among all the participants were: asthma (24.9\%), asthma-like symptoms (19.0\%), protracted bacterial bron- chitis (PBB) (11.9\%), and upper airway cough syndrome (9.1\%) [9]. In an Australian multicenter study, $41 \%$ of 346 children who had a chronic wet cough, after a thorough examination, were diagnosed with PBB [8].

The persistent bacterial infection of the lower respiratory tract is the basis of PBB pathogenesis. The most common cause of PBB is atypical $\mathrm{H}$. influenzae (47-81\%), S. pneumoniae (24-39\%), M. catarrhalis (19-43\%), which were isolated from the bronchoalveolar lavage samples $[10,11]$. The occurrence of PBB is associated with the violation of mucociliary clearance, immune deficiency, airway abnormalities and bacterial biofilms formation in the respiratory tract [12].

PBB is often misdiagnosed (for example, as asthma) or inadequately treated, which leads to symptoms persistence and potential structural damage to the respiratory system $[13,14]$.

PBB require complex differential diagnostics. They need to be differentiated with acute bronchitis of viral etiology. Other reasons which should be considered are foreign body in respiratory tract and cough due to adenotonsillar hypertrophy. Cystic fibrosis, bronchiectasis, primary ciliary dyskinesia, pulmonary aspiration and immunodeficiency are rare but important differential diagnoses [15].

Due to the fact that protracted bacterial bronchitis today remains an understudied problem in Ukraine, it is relevant to study its clinical, anamnestic and microbiological features, as well as their role in the development of CB in children.

\section{The purpose}

The purpose is to study the clinical-anamnestic and microbiological features of PBB, RB and $\mathrm{CB}$ in children and to determine the risk factors for $\mathrm{CB}$ development.

\section{Materials and methods}

To achieve the goal, a comprehensive survey was conducted including 89 children aged from 6 months to 18 years, who had complaints of prolonged wet cough (more than 4 weeks). Among the examined children, the groups of patients with $\mathrm{RB}$ and $\mathrm{CB}$ (according to diagnoses already documented earlier in the primary medical documentation) and a group of children with the first episode of bronchitis with a protracted course (that is, possibly PBB) were identified. Exclusion criteria were: the presence of hereditary or congenital bronchopulmonary pathology (bronchial asthma, cystic fibrosis, primary ciliary dyskinesia, deficiency of alpha-1-antitrypsin, congenital malformations of bronchus and lungs), microaspiration syndrome, immunodeficiency, congenital heart disease, tobacco smoking.

After selection, all the examined children were divided into 3 groups. The first group consisted of 21 children with PBB (average age $-3.8 \pm 0.6$ years), the second group 27 children with RB (average age $-13.2 \pm 2.1$ years) and 


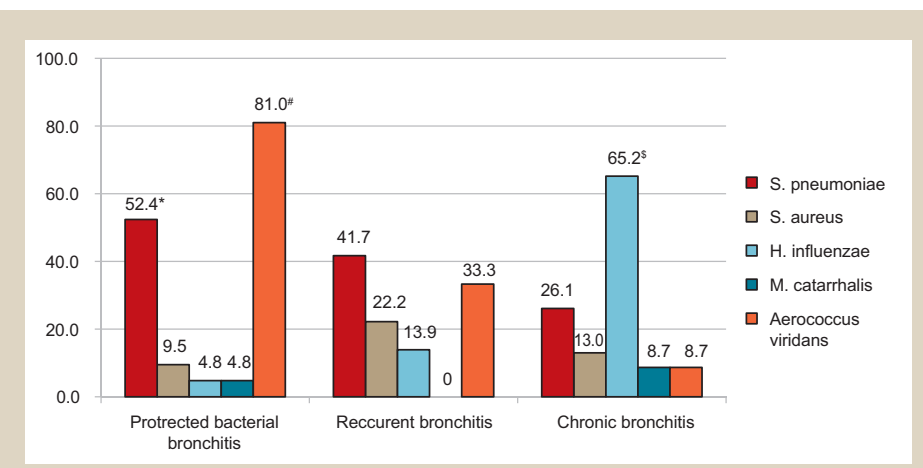

*: significance of differences compared with the third group $(P<0.05)$; \#: significance of differences compared with the second and the third group $(P<0.05)$; $\$$ : significance of differences compared with the first and the second group $(P<0.05)$.

Fig. 1. The structure of the identified microflora (\%) in the bronchoalveolar lavage fluid of patients.

the third group -41 child with $\mathrm{CB}$ (average age $-14.7 \pm 2.6$ years).

Parents of patients received complete information on the scope of diagnostic measures and signed a written consent to participate in the study.

Instrumental methods of examination included chest X-ray and bronchoscopy. The study of qualitative and quantitative microbial composition of bronchial mucosa was performed in bronchoalveolar lavage fluid obtained during diagnostic and therapeutic bronchoscopy according to the standard method. In addition, the microbial spectrum of the upper respiratory tract obtained by oropharyngeal deep swabbing was studied. The conclusion was made based on a staining reaction presence on plates. The museum strain Aerococcus viridans № 167 was used as a control strain.

All statistical calculations were performed by means of Statistica v 6.1 (license number - AGAR909E415822FA). Quantitative and qualitative indicators were evaluated. Descriptive statistics were presented in the form of average and standard error of mean $(\mathrm{M} \pm \mathrm{m})$ for values with normal distribution. Statistical significance was defined at $\mathrm{P}<0.05$.

\section{Results}

Analysis of PBB clinical features showed that their total duration was $4.1 \pm 0.3$ weeks in the 1 st group children; the duration of exacerbations did not differ significantly and was $3.8 \pm 0.6$ weeks $(P>0.05)$ in the 2 nd group children. In patients with $\mathrm{CB}$, the annual number of bronchitis and the total duration of cough were two times higher than in patients with $\mathrm{RB}(4.5 \pm 0.2$ vs $2.6 \pm 0.3$ times; $4.3 \pm 0.3$ vs $2.2 \pm 0.2$ months, respectively, $P<0.001)$. There were found significant differences in repeated bronchitis duration in patients with $\mathrm{RB}$ and $\mathrm{CB}(3.2 \pm 0.8$ vs $6.2 \pm 1.1$ years, $P<0.05)$.

According to X-ray data, all patients including PBB demonstrated an increase in vascular pattern and pulmonary hilum enlargement was revealed in $19.0 \%$ of patients. In CB patients as compared to RB patients, the following signs were more common: increased vascular pattern ( $73.2 \%$ vs $40.7 \%, P<0.01$ ), pulmonary hilum enlargement and consolidation $(65.9 \%$ vs $11.1 \%, P<0.001)$. Deformation of the vascular pattern was inherent in $\mathrm{CB}$ patients and was found in all the patients of this group without any exception (100\%), while it was revealed in only one child ( $P<0.001)$ among RB patients. Emphysematosis, attenuation differences, pulmonary tissues infiltration were found in children with CB $(24.4 \%, 17.1 \%, 7.3 \%$, respectively $)$ and were absent in children with RB. In the first two cases, the differences were significant with $P<0.01$ and $P<0.05$, respectively.

The results of endobronchial examination showed visual signs of hypotension of the trachea and bronchi in half of CB patients ( $51.2 \%$ ), which is one of the risk factors for the drainage function of the bronchi disturbance. Endobronchitis was mostly diffuse (in $61.0 \%$ of the subjects) and catarrhal-purulent (58.5\%), catarrhal (26.8\%) and purulent $(14.6 \%)$ by the nature in this study group. In assessing the bronchial epithelial layer condition, the moderate signs of the mucous membrane atrophy were noted in $34.1 \%$ of cases and the bronchial epithelial dysplasia was noted in $46.3 \%$. In patients with RB, visual signs of the bronchial mucous membrane atrophy or dysplasia were not recorded in any case.

Comparison of bronchial signs in patients with $\mathrm{CB}$ and $\mathrm{RB}$ showed a difference in the frequency of tracheal and bronchial mobility reduction ( $51.2 \%$ vs $18.5 \%, P<0.01)$, the bronchial wall hypertrophy $(19.5 \%$ vs $3.7 \%, P<0.05)$, the nature of endobronchitis (catarrhal purulent $58.5 \%$ vs $33.3 \%, P<0.05$, purulent $14.6 \%$ in the absence of it in children with RB, $P<0.05$, catarrhal $-26.8 \%$ vs $66.7 \%$, $P<0.05)$. There was no significant difference $(P>0.05)$ between the frequency of bilateral $(65.9 \%$ vs $74.1 \%)$ and left sided endobronchitis ( $17.1 \%$ vs $25.9 \%)$, bronchial edema $(22.0 \%$ vs $14.8 \%)$.

The analysis of the cytomorphological studies results of brush biopsy material from the bronchial mucous membrane of $\mathrm{RB}$ and $\mathrm{CB}$ patients in the remission period confirmed the infiltration of inflammatory cells into bronchial mucosa. A comparative analysis of the brush biopsy specimens for cellular structure from the bronchial mucosa of the examined children also confirmed that the features of $C B$ inflammation in the clinical remission period were mainly lymphocytic-macrophage infiltration and RB - neutrophilic-macrophage infiltration.

The bacteriological analysis of sputum showed that the most frequent cause of the disease in children with PBB and exacerbation of RB was Streptococcus pneumonia (52.4 \% and $41.7 \%$, respectively). Staphylococcus aureus was detected in $9.5 \%$ of PBB patients and in $22.2 \%$ of RB patients, Haemophilus influenzae was found in $4.8 \%$ and $13.9 \%$ of sick children, respectively. In children with CB exacerbation, Haemophilus influenzae was identified significantly more frequently (in $65.2 \%$ of cases, $P<0.05$ ), Streptococcus pneumonia was detected in $26.1 \%$ of patients, Staphocloccus aureus and Moraxella catarrhalis were identified in $13.0 \%$ and $8.7 \%$ of patients, respectively (Fig. 1).

At the same time, monocultures of Haemophilus influenzae were defined approximately in $70 \%$, Streptococcus pneumonia and Moraxella catarrhalis - in about $50 \%$ of cases.

Aerococcus viridans, as a representative of the normal bronchial microbiome, was identified in $81.0 \%$ of PBB patients, only in one third of RB children (33.3\%) and in $8.7 \%$ of $\mathrm{CB}(\mathrm{P}<0.05)$ in the clinical remission periods 
(Fig. 2). In the period of exacerbation, there was no case of the microorganism identification.

An association between dysbiotic disorders in the bronchi (in the form of the normal microflora decreased activity or none at all) and such anamnestic data as the beginning of $R B$ in preschool age $(r=0.39, P<0.01)$ and repeated courses of antibiotic therapy $(r=0.53, P<0.001)$ was established.

\section{Discussion}

Thus, today, in different international guidelines, there is a mixed approach to the term "chronic cough" in children. In our opinion, it would be rational to use the classification of cough taking into account the age of patients, because age-related anatomical and functional features influence the pathological changes in the bronchi.

The existence of PBB as a new nosological group is also a debatable issue. This is due to the fact that PBB, as a separate nosological form, is not in the ICD-10. In addition, its diagnostic criteria do not correspond to any forms of bronchitis, presented in the domestic clinical classification of bronchopulmonary diseases in children. It should be foreseen that until there are unified approaches to PBB diagnosis, there will be no reliable statistics for the disease among children, in particular in Ukraine. In our opinion, one way to overcome this problem could be to register children under 6 years of age with a subacute course of bronchitis (corresponding to ICD-10 J20) as patients with PBB (it must be taken into account as the terms of bronchitis course and bacterial etiology as well as the age of a patient).

Our study confirmed that children of pre-school age mainly suffer from protracted bacterial bronchitis (the average age of children was $3.8 \pm 0.6$ years). The duration of bronchitis was $4.1 \pm 0.3$ weeks corresponding to the literature data $[5,7]$.

It is assumed that PBA is the predictor of chronic purulent bronchitis [16]. Ukrainian scientists believe that the risk group for chronic bronchitis development are children with recurrent lower respiratory tract infection, namely with recurrent bronchitis [17]. Studies conducted by Yu. G. Antipkin, K. D. Duka et al. allowed to identify a group of children with "transitional forms" of recurrent bronchitis, which require the same treatment approaches as chronic bronchitis $[17,18]$. Perhaps in this group there are children with recurring PBB. Danielle F. Wurzel has shown that recurrent PBB in children and Haemophilus influenzae persistence in the respiratory tract are the risk factors for bronchiectasis [19]. Bronchiectasis, as a variant of acquired pathology, should be considered as signs of chronic deforming endobronchitis.

Regarding Haemophilus influenzae presence in the microbiota of the respiratory tract in children, our study shows that this pathogen was significantly more common among children with chronic bronchitis enabling it to be considered as one of the risk factors for chronic inflammation.

In addition, normal microbiota of the lower respiratory tract mucous membrane, in particular Aerococcus viridans, plays a very important role in chronic bronchopulmonary inflammation in RB children that was confirmed in our previous studies [15,17]. The characteristics identification of such bronchitis course in the absence of Aerococcus

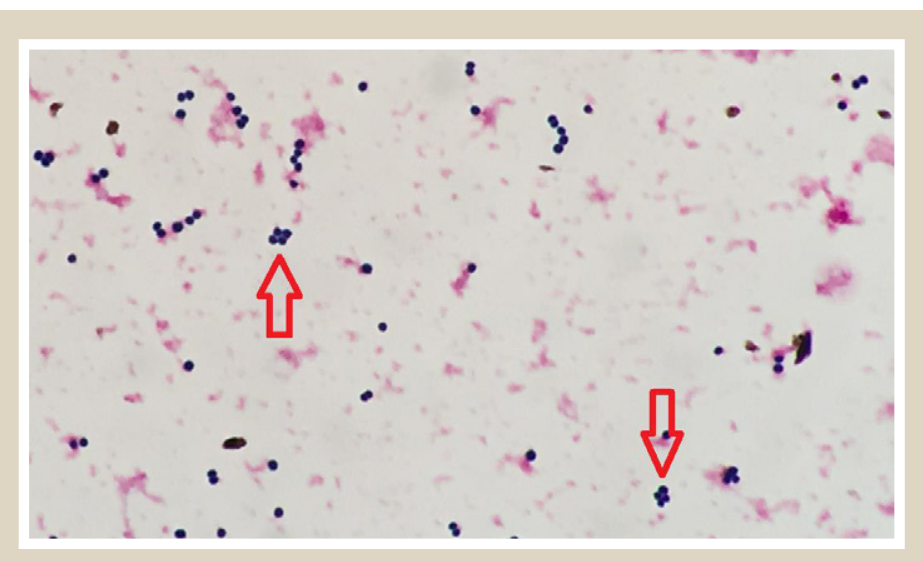

Fig. 2. Aerococcus viridans are gram-positive, arranged in pairs and tetrads (photo, contrast microscopy, $\times 400$ )

viridans in bronchial secretion is of significant importance as it is accompanied by frequent and prolonged exacerbations and intoxication syndrome.

\section{Conclusions}

1. Protracted bacterial bronchitis in modern conditions should be considered as a variant of the subacute course of bronchitis, due to specific microbiotic disorders in the bronchi and age-related anatomical and functional characteristics of preschool children.

2. Protracted bacterial bronchitis is predominantly typical for preschool children with average duration of $4.1 \pm 0.3$ weeks. In children with recurrent bronchitis, the duration of exacerbations does not differ significantly and lasts for $3.8 \pm 0.6$ weeks. Streptococcus pneumonia is the most frequent causative agent of protracted bacterial and recurrent bronchitis and Haemophilus influenzae - of chronic bronchitis.

3. The risk factors for chronic bronchitis development in children with protracted bacterial and recurrent bronchitis are the lower respiratory tract $\mathrm{H}$. influenzae colonization and decreased activity or absence of normal airway microbiota (Aerococcus viridans).

The perspective for further scientific research is to develop personalized preventive programs for patients with high risk for chronic bronchopulmonary pathology.

\section{Funding}

The study is a fragment of the research work of the Department of Propedeutics of Pediatric Diseases of SI "Dnipropetrovsk Medical Academy of the Ministry of Health of Ukraine":

"Clinical and functional features of bronchitis in children against the background of various comorbid conditions, prevention and prediction of their course" (State registration number 0116U004962, 2017-2019 years).

Conflicts of interest: authors have no conflict of interest to declare. Конфлікт інтересів: віАсутній. 
Information about authors:

Ilchenko S. I., MD, PhD, DSc, Professor of the Department of Propedeutics of Pediatric Diseases, SI "Dnipropetrovsk Medical Academy of the Ministry of Health of Ukraine", Dnipro. Fialkovska A. O., MD, PhD, Assistant of the Department of Propedeutics of Pediatric Diseases, SI "Dnipropetrovsk Medical Academy of the Ministry of Health of Ukraine", Dnipro. Zhukova L. O., MD, Assistant of the Department of Propedeutics of Pediatric Diseases, SI “Dnipropetrovsk Medical Academy of the Ministry of Health of Ukraine", Dnipro.

\section{Відомості про авторів:}

Ільченко С. І., А-р меА. наук, професор каф. пропеАевтики Аитячих хвороб, АЗ “Аніпропетровська медична академія МОЗ України", м. Аніпро.

Фіалковська А. О., канА. меА. наук, асистент каф. пропедевтики Аитячих хвороб АЗ "Аніпропетровська медична академія МОЗ України", М. Аніпро.

Жукова А. О., асистент каф. пропеАевтики Аитячих хвороб, АЗ "Аніпропетровська медична акаАемія М03 України", м. Аніпро.

\section{Сведения об авторах:}

Ильченко С. И., А-р меА. наук, профессор каф. пропедевтики Аетских болезней, ГУ "Анепропетровская медицинская акаАемия МЗ Украины", г. Анипро.

Фиалковская А. А., канА. меА. наук, ассистент каф. пропеАевтики Аетских болезней ГУ “Анепропетровская медицинская академия МЗ Украины", г. Анипро.

Жукова ^. А., ассистент каф. пропедевтики Аетских болезней, ГУ "Анепропетровская медицинская академия МЗ Украины", г. Анипро.

\section{References}

[1] Shields, M. D., Bush, A., Everard, M. L., McKenzie, S., \& Primhak, R. (2008). British Thoracic Society Cough Guideline Group. BTS guidelines: Recommendations for the assessment and management of cough in children. Thorax, 63(3), iii1-iii15. doi: 10.1136/ thx.2007.077370

[2] MOZ Ukrainy (2015) Unifikovanyi klinichnyi protokol pervynnoi medychnoi dopomohy «Kashel u ditei vikom vid shesty rokiv» [Unified clinical protocol for primary care "Cough in children from six years old"]. Kyiv. [in Ukrainian].

[3] Samsygina, G. A. (2015). Khronicheskij kashel' v detskom vozraste [Chronic cough in children] Pediatriya. Zhurnal im. G. N. Speranskogo, 94(4), 163-170. [in Russian].

[4] Marchant, J. M., Masters, I. B., Taylor, S. M., Cox, N. C., Seymour, G. J., \& Chang, A. B. (2006). Evaluation and outcome of young children with chronic cough. Chest, 129(5), 1132-1141. doi: 10.1378/ chest.129.5.1132

[5] Kantar, A., Chang, A. B., Shields, M. D., Marchant J. M., Grimwood K., Grigg J., et al. (2017). ERS statement on protracted bacterial bronchitis in children. European Respiratory Journal, 50(2). doi: $10.1183 / 13993003.02139-2016$

[6] Filippo, P. D., Scaparrotta, A., Petrosino, M. I., Attanasi, M., Di Pillo S., Chiarelli F, \& Mohn, A. (2018). An underestimated cause of chronic cough: The protracted bacterial bronchitis. Annals of Thoracic Medicine, 13(1), 7-13. doi: 10.4103/atm.ATM_12_17. doi: 10.4103/ atm.ATM 12 17

[7] Craven, V., \& Everard, M. L. (2013) Protracted bacterial bronchitis: Reinventing an old disease. Arch Dis Child, 98(1), 72-76. doi: 10.1136/ archdischild-2012-302760

[8] Chang, A. B., Robertson, C. F., Van Asperen, P. P., Glasgow, N. J., Mellis, C. M., Masters, I. B., et al. (2012). Amulticenter study on chronic cough in children: Burden and etiologies based on a standardized management pathway. Chest, 142(4), 943-950. doi: 10.1378/chest.11-2725

[9] Gedik, A. H., Cakir, E., Torun, E., Demir, A. D., Kucukkoc, M., Erenberk, U., et al. (2015). Evaluation of 563 children with chronic cough accompanied by a new clinical algorithm. Ital J Pediatr, 41(1), 1-7. doi: 10.1186/s13052-015-0180-0

[10] Bidiwala, A., Krilov, L. R., Pirzada, M., \& Patel, S. J. (2015). Pro-Con Debate: Protracted Bacterial Bronchitis as a Cause of Chronic Cough in Children. Pediatr Ann, 44(8), 329-336. doi: 10.3928/00904481 20150812-11

[11] Zgherea, D., Pagala, S., Mendiratta, M., Marcus, M. G., Shelov, S. P. \& Kazachkov, M. (2012). Bronchoscopic findings in children with chronic wet cough. Pediatrics, 129(2), 364-369. doi: 10.1542/peds. 2011-0805
[12] Paul, S. P., \& Hilliard, T. (2014) The importance of recognizing protracted bacterial bronchitis in children. Indian J Pediatr, 81(1), 1-3. doi: 10.1007/s12098-013-1197-2

[13] Craven, V., \& Everard, M. L. (2013). Protracted bacterial bronchitis: Reinventing an old disease. Arch Dis Child, 98(1), 72-6. doi: 10.1136/ archdischild-2012-302760

[14] Narang, R., Bakewell, K., Peach, J., Clayton, S., Samuels, M., Alexander, J., et al. (2014) Bacterial distribution in the lungs of children with protracted bacterial bronchitis. PLoS One, 9(9), e108523. doi: 10.1371/ journal.pone. 0108523

[15] Ilchenko, S. I., \& Fialkovska, A. O. (2018). Diahnoz «khronichny bronkhit» v dytiachii pulmonolohii: «za» ta «proty» [Diagnosis "chronic bronchitis" in children's pulmonology: "pro" and "contra"]. Ukrainskyi pulmonolohichnyi zhurnal, 4, 32-34. [in Ukrainian].

[16] Goyal, V., Grimwood, K., Marchant, J. M., Masters, I. B., \& Chang, A. B (2016). Paediatric chronic suppurative lung disease: clinical characteristics and outcomes. Eur J Pediatr, 175(8), 1077-1084. doi: 10.1007 / s00431-016-2743-5

[17] Duka, K. D., Ilchenko, S. I., \& Ivanus, S. G. (2013). Khronichnyi bronkhit u ditei ta pidlitkiv - mynule, suchasne i maibutnie [Chronic bronchitis in children and adolescents - past, present and future]. Dnipropetrovsk. [in Ukrainian].

[18] Antipkin, Y. G., Lapshin, V. F., Umanec, T. R. (2009). Recidiviruyushhij bronkhit u detej: diskussionnye voprosy [Recurrent bronchitis in children: discussion questions]. Zdorovia Ukrainy, 18(1), 19-21. [in Russian].

[19] Wurzel, D. F., Marchant, J. M., Yerkovich, S. T., Upham, J. W. Petsky, H. L., Smith-Vaughan, H., et al. (2016). Protracted Bacteria Bronchitis in Children: Natural History and Risk Factors for Bronchiectasis. Chest, 150(5), 1101-1108. doi: 10.1016 / j.chest.2016.06.030 